\title{
The Effect of Cytokines on Parathyroid Hormone-Related Protein (PTH-rP) Production in Human Amnion Cells
}

\author{
KIYotaKe ICHIZUKA, TARo MORIMOTO, MaKoto SUZUKI, YASUShi SASAKI, Hitomi KURIHARA, \\ HIROSHI SAITO AND TAKUMI YANAIHARA
}

Department of Obstetrics and Gynecology, Showa University School of Medicine, 1-5-8 Hatanodai, Shinagawa-ku, Tokyo 142-8666, Japan

\begin{abstract}
In the present study, the effects of various cytokines on parathyroid hormone-related protein (PTH-rP) production and PTH-rP mRNA expression in human amnion cells were studied. Immunoreactive (ir) PTH-rP was measured by immunoradiometric assay and the expression of PTH-rP mRNA was determined by Northern blot analysis. The addition of interleukin- $\beta$ (IL-1 $\beta, 10 \mathrm{ng} / \mathrm{ml})$ and IL-6 $(10 \mathrm{ng} / \mathrm{ml})$ in culture medium for 24 hours resulted in a significant increase in ir-PTH-rP levels by 1.5 and 1.6 fold, respectively. The effects of these agents were dose dependent. In contrast, IL-2 $(10 \mathrm{ng} / \mathrm{ml})$ and IL-8 $(10 \mathrm{ng} / \mathrm{ml})$ showed no effect on the production of ir-PTH-rP from amnion cells. Treatment with IL-1 $\beta$ or IL- 6 for 6 hours increased the expression of PTH-rP mRNA in amnion cells. The stimulatory effect of IL- $1 \beta$ was reduced by IL-1 receptor antagonist (IL-1Ra) in a dose dependent manner. Both tetradecanoyl phorbol acetate (TPA), and forskolin increased PTH-rP mRNA levels and the PTH-rP production in amnion cells, and the effect of TPA was much greater than that of forskolin. The findings of the present study suggest of the participation of inflammatory cytokines for the regulation of PTH-rP production in human amnion cells.
\end{abstract}

Key words: Parathyroid hormone-related protein, mRNA, Amnion cell, Cytokine

(Endocrine Journal 46: 479-486, 1999)

PARATHYROID hormone-related protein (PTHrP) was discovered as a hypercalcemia-inducing product of malignant tumors [1]. The protein shares sufficient amino-terminal homology with parathyroid hormone (PTH) that can activate adenyl cyclase via PTH/PTH-rP receptor. While PTH gene has a simple structure and appears to be expressed principally by the parathyroid gland, the PTH-rP gene has a complex organization and is expressed in a wide variety of normal tissues and cell types including the tissues of fetus and those of the reproductive tract [2-8]. Amnion tissue is known to express quite a large amount of PTH-rP during pregnancy. Shew et

Received: October 28, 1998

Accepted: January 25, 1999

Correspondence to: Dr. Kiyotake ICHIZUKA, Department of Obstetrics and Gynecology, Showa University School of Medicine, 1-5-8 Hatanodai, Shinagawa-ku, Tokyo 142-8666, Japan al. demonstrated that the $\mathrm{N}$-terminal of the first 34 amino acids of PTH-rP reduced the magnitude of acetylcholine stimulated uterine contraction in rats [9]. Pitera et al. found that PTH-rP inhibited the contractile effect of high doses of oxytocin in the lower segment, corpus, and fundus of the baboon uterus [10]. Furgason et al. found that PTH-rP mRNA in amnion was decreased by $78 \%$ after rupture of the fetal membrane [6]. Intrauterine occupancy and stretching of the uterine cavity may stimulate PTH-rP production in human amnion, and PTH-rP would be quiescent the uterus, allowing it to accommodate the growing fetus. The PTH-rP concentration in amniotic fluid is approximately 15 times higher than in either fetal or maternal plasma and its concentration is comparable to those found in the plasma of patients with humoral hypercalcemia of malignancy [11]. There are several reports on the PTH-rP concentration in amniotic fluid during pregnancy. Dvir et al. collected amniotic fluid at 16-18 
weeks of gestation and term and reported that the levels of PTH-rP did not change during pregnancy [12]. In contrast, Wlodek et al. reported that the PTH-rP concentration in amniotic fluid is greater at term (37-42 weeks) than in the middle of gestation (15-36 weeks) [13, 14], but the mechanism of regulation of PTH-rP in human amnion which is thought to be one of the major sources of PTH-rP in amniotic fluid is not clear yet. Many groups of investigators have evaluated amniotic fluid collected during normal and preterm labor to identify and quantify mediators of inflammation. For example IL- $1 \beta$, a primary cytokine produced rapidly in response to infection, which acts in many cells to promote the synthesis of many other cytokines and other mediators of inflammation [15]. IL-6 levels in amniotic fluid were much higher in the group of intrauterine infections such as chorioamnionitis than in those without infection [16, 17]. It is now known that preterm labor induced by an increase in inflammatory cytokine is promoted by the production of prostaglandins in decidua, but the effect of inflammatory cytokines on PTH-rP production in amnion cells is unclear. The aim of this study was to determine whether inflammatory cytokines regulate the production of PTH-rP and expression of PTH-rP mRNA in amnion cells.

\section{Materials and Methods}

\section{Chemicals}

IL- $1 \beta$ was kindly provided to us by Otsuka Pharmaceutical Co., Ltd. IL-2, IL-6 and IL-8 were purchased from R \& D systems Inc. (Minneapolis, MN, USA). TPA was purchased from Sigma Chemical Company (St. Louis, MO, USA). Foskolin were purchased from BIOMOL Research Laboratories Inc. (Plymouth Meeting, PA, USA). Recombinant human IL-1 receptor antagonist was purchased from Pepro Tech EC Ltd (St. James' Square, London, England). All other chemicals were reagent grade.

\section{Isolation and culture of human amnion cells}

Amnion tissues were obtained from normal pregnancies at the time of elective Cesarean section conducted before the onset of labor at 37 to 41 weeks of gestation. Informed consent for the use of these tissues was obtained from each patient and our study was approved by the ethical committee of Showa University School of Medicine prior to the surgical procedure. Immediately after delivery, the reflected amnion was separated from the chorion laeve by gentle traction. Isolation of amnion epithelial cells was carried out based on procedures described by Rice Okita et al. [18]. Briefly, The reflected amnion was placed in Hanks' balanced salt solution (HBSS) (GIBCO, BRL) that contained penicillin G (GIBCO, BRL) $(200 \mathrm{U} / \mathrm{ml})$, streptomycin sulfate (GIBCO, BRL) $(200 \mu \mathrm{g} / \mathrm{ml})$, and amphotericin B (GIBCO, BRL) $(0.5 \mu \mathrm{g} / \mathrm{ml})$. The amnion was rinsed in HBSS until free of blood contamination and then minced with a scalpel into approximately 20 - to $50 \mathrm{~mm}^{2}$ pieces. Then amnion tissue was digested twice with a digestioning solution consisting of basal medium (BM; Dulbecco's Modified Eagle Media/Ham's F-12) (GIBCO, BRL) supplemented with trypsin (GIBCO, BRL) $(5 \mathrm{mg} / \mathrm{ml})$, deoxyribonuclease (BOEHRINGER MANNHEIM GmbH, Mannheim, Germany) $(1.5 \mathrm{mg} / \mathrm{ml})$, penicillin $\mathrm{G}(100 \mathrm{U} / \mathrm{ml})$, streptomycin sulfate $(100 \mu \mathrm{g} / \mathrm{ml})$ and amphotericin $\mathrm{B}(0.25 \mu \mathrm{g} / \mathrm{ml})$ at $37^{\circ} \mathrm{C}$ in humidified air with $5 \% \mathrm{CO}_{2}$ for $120 \mathrm{~min}$. Nonisolated fragments were separated by filtration through a nylon mesh. The isolated amnion cells were cultured in DMEM/F12 medium supplemented with $10 \%$ fetal bovine serum (JRH Bioscience), penicillin $\mathrm{G}(100 \mathrm{U} / \mathrm{ml})$, streptomycin sulfate $(100$ $\mu \mathrm{g} / \mathrm{ml})$, and amphotericin $\mathrm{B}(0.25 \mu \mathrm{g} / \mathrm{ml})$ at $37^{\circ} \mathrm{C}$ in humidified air with $5 \% \mathrm{CO}_{2}$. With this procedure, we obtained $4 \times 10^{7}$ amnion epithelial cells from 10 $15 \mathrm{~g}$ amnion tissue with a cell viability of approximately $80 \%$, as determined by trypan blue $(0.05 \%)$ exclusion.

\section{PTH-rP production in amnion cell culture}

Confluent amnion cells in primary culture were passed by standard methods of trypsinization, plated in 6 well dishes and maintained in growth medium until the cells reached confluence. When confluence was attained, the amnion cells were pre-incubated for 24 hours in serum-free DMEM/F12 which contained bovine serum albumin (Wako Pure Chemical Industries, Ltd) $(0.1 \%, \mathrm{w} / \mathrm{v})$, penicillin $\mathrm{G}(100 \mathrm{U} / \mathrm{ml})$, streptomycin sulfate $(100 \mu \mathrm{g} / \mathrm{ml})$ and amphotericin B $(0.25 \mu \mathrm{g} / \mathrm{ml})$. After 24 hours the medium was 
changed to that which contained the test agents in the serum free DMEM/F12. Amnion cells were incubated with the test agents for 24 hours. The concentrations of test agents were IL- $1 \beta(0.1 \mathrm{ng} / \mathrm{ml}, 1$ $\mathrm{ng} / \mathrm{ml}, 10 \mathrm{ng} / \mathrm{ml}), \mathrm{IL}-2(10 \mathrm{ng} / \mathrm{ml})$, IL-6 $(0.1 \mathrm{ng} / \mathrm{ml}$, $1 \mathrm{ng} / \mathrm{ml}, 10 \mathrm{ng} / \mathrm{ml})$, IL-8 $(10 \mathrm{ng} / \mathrm{ml})$, IL-1 Ra $(20$ $\mathrm{ng} / \mathrm{ml}, 50 \mathrm{ng} / \mathrm{ml})$, forskolin $\left(1 \times 10^{-6} \mathrm{M}\right)$ and TPA $\left(1 \times 10^{-7} \mathrm{M}\right)$. Six wells were used for each concentration. The media were collected into tubes containing aprotinin and stored at $-80^{\circ} \mathrm{C}$ until assayed for PTH-rP. Cell count was performed in experiments after the media were collected and the PTH-rP concentration was expressed as per $10^{5}$ cells. Immunoreactive-PTH-rP (ir-PTH-rP) in the culture media was measured by two site immunoradiometric assay [19] (PTH-rP IRMA “Mitsubishi”) (Mitsubishi Chemical Corp., Japan) which employ two specific antibodies to PTH-rP (1-34) and PTH-rP (50-83). This kit uses recombinant human PTH-rP (1-87) as PTH-rP calibrator. There was no cross-reactivity with PTH. The detection limit of this assay is 1 pmol/1. The intra-and inter-assay coefficients of variation were $9 \%$ and $6 \%$, respectively.

\section{Northern blot analysis}

First passed amnion cells were grown in $10 \mathrm{~cm}$ dishes. When confluence was attained, the cells were transferred to medium containing bovine serum albumin $(0.1 \%, \mathrm{w} / \mathrm{v})$ for 24 hours and then, treated for 6 hours with IL- $1 \beta(10 \mathrm{ng} / \mathrm{ml})$, IL-6 $(10 \mathrm{ng} / \mathrm{ml})$, forskolin $\left(1 \times 10^{-6} \mathrm{M}\right)$ or TPA $\left(1 \times 10^{-7}\right)$. The cells were harvested for extraction of total RNA. Total RNA was extracted from amnion cells with TRIZOL (GIBCO BRL) by the acid guanidium-phenolchroloform (AGPC) method. Aliquots of total RNA were size-fractionated by electrophoresis on agarose (1\%) gels with $15 \mu \mathrm{g}$ of RNA per lane and transferred overnight onto Hybond-N + membrane (Amersham LIFE SCIENCE). The RNA was immobilized on membrane after exposure to UV irradiation and pre-hybridized in pre-hybridization buffer $50 \%$ formamide, $5 \times \mathrm{SSC}, 50 \mathrm{mM}$ sodium phosphate, $10 \times$ Denhardt solution, $5 \%$ dextran sulfate and $0.5 \mathrm{mg} / \mathrm{ml}$ denatured salmon sperm DNA), for 24 hours at $42^{\circ} \mathrm{C}$. Hybridization was performed in Hybridization buffer $(50 \%$ formamide, $5 \times \mathrm{SSC}$, $20 \mathrm{mM}$ sodium phosphate, $2 \times$ Denhardt solution, $10 \%$ dextran sulfate, $0.1 \mathrm{mg} / \mathrm{ml}$ denatured salmon sperm DNA $)$ and probe $\left(1 \times 10^{6} \mathrm{Ccpm} / \mathrm{ml}\right.$ hybridization mix) for 24 hours at $42^{\circ} \mathrm{C}$. The human PTH-rP cDNA probe (kindly provided to us by Geoffrey N. Hendy, Ph. D. Calcium Research Lab., Royal Victoria Hospital.) was labeled with $\left[\alpha^{32} \mathrm{P}\right] \mathrm{dCTP}$ by the random hexamer priming method (TAKARA random primer DNA labeling kit ver. 2.). After hybridization, blots were washed twice in $0.1 \times \mathrm{SSC}$, $0.1 \%$ SDS for $15 \mathrm{~min}$ at room temperature, followed by each 30 washing in $0.1 \times \mathrm{SSC}, 0.1 \% \mathrm{SDS}$ at $42^{\circ} \mathrm{C}$ and $50^{\circ} \mathrm{C}$. The membrane was blotted on filter paper, sealed in a plastic bag, and exposed for 18 hours to Amersham X-Omat film at $-70^{\circ} \mathrm{C}$ with an intensifying screen. The intensity of the blots was quantified by imaging densitometry (BIO-RAD). As a control for the amount of RNA loaded, the membrane was also probed with the constitutively expressed gene for $\beta$-actin.

\section{Statistical analysis}

The results are presented as the mean \pm SD and were analyzed by one-way analysis of variance (ANOVA) with multiple comparison tests or repeated measures. Statistical significance was taken as $\mathrm{p}<0.05$.

\section{Results}

\section{Effect of cytokines, TPA and forskolin on PTH-rP production in human amnion cells}

Conditioned medium collected from amnion cells contained ir-PTH-rP. The rate of ir-PTH-rP production significantly $(\mathrm{p}<0.01)$ increased with IL$1 \beta$ and IL-6, but treatment with IL- 2 and IL- 8 did not alter ir-PTH-rP production. The levels of ir-PTH$\mathrm{rP}$ were $2.36 \pm 0.37 \mathrm{pmol} / \mathrm{l} / 24 \mathrm{~h} / 5 \times 10^{5}$ cells in the control, $4.21 \pm 0.24$ in media treated with IL- $1 \beta$ (10 $\mathrm{ng} / \mathrm{ml}), 2.28 \pm 0.31$ in media treated with IL-2 (10 $\mathrm{ng} / \mathrm{ml}), 3.43 \pm 0.78$ in media treated with IL-6 (10 $\mathrm{ng} / \mathrm{ml})$ and $2.57 \pm 1.02$ in media treated with IL-8 (10 $\mathrm{ng} / \mathrm{ml}$ ) (Fig. 1). IL-1 $\beta$ and IL-6 stimulated PTH-rP production in a dose dependent manner (Fig. 2). Whereas IL-1 Ra $(20 \mathrm{ng} / \mathrm{ml}, 50 \mathrm{ng} / \mathrm{ml})$ did not alter ir-PTH-rP production from amnion cells, the accumulation of ir-PTH-rP by IL- $1 \beta(10 \mathrm{ng} / \mathrm{ml})$ was significantly diminished by the addition of IL-1 Ra (50 


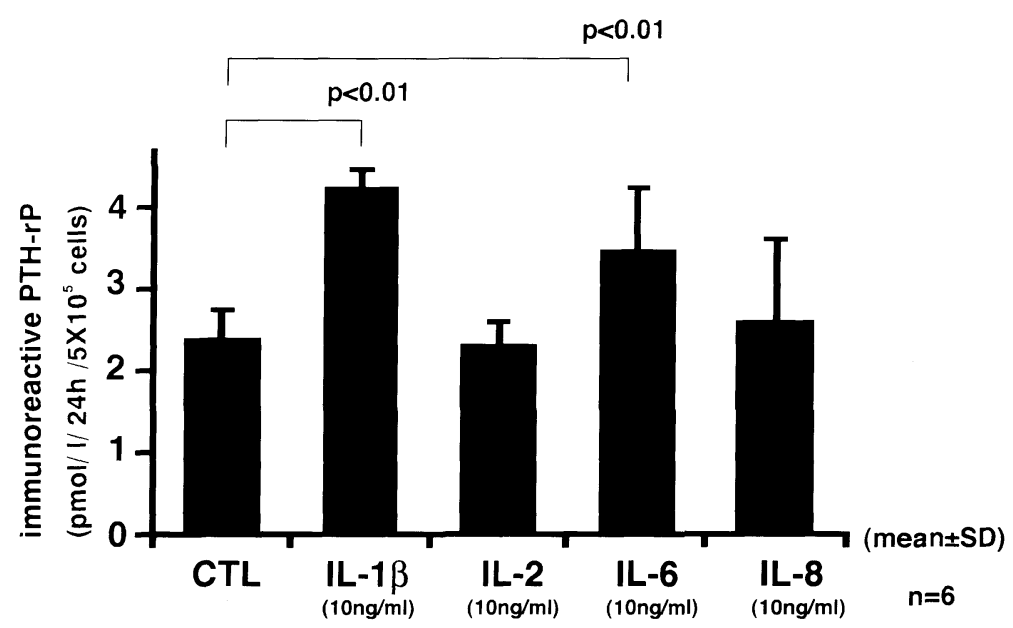

Fig. 1. Human amnion cells were isolated and maintained in monolayer culture. $80 \%$ confluent amnion cells [preincubated for $24 \mathrm{~h}$ in serum free medium] were treated with IL-1 $\beta(10 \mathrm{ng} / \mathrm{ml})$, IL-2 $(10 \mathrm{ng} / \mathrm{ml})$, IL-6 $(10 \mathrm{ng} / \mathrm{ml})$ and IL-8 $(10 \mathrm{ng} / \mathrm{ml})$ for $24 \mathrm{~h}$. The rate of ir-PTH-rP formation (accumulation) increased with IL-1 $\beta$ and IL-6. Treatment with IL-2 or IL-8 did not have any affect on PTH-rP production. The results were analyzed by one-way ANOVA with multiple comparison tests.
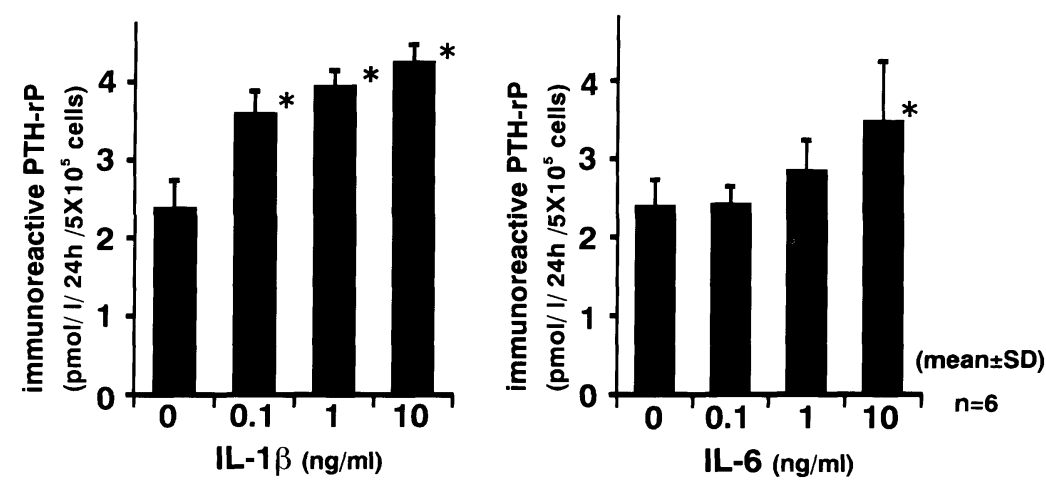

Fig. 2. Human amnion cells in serum free medium were treated for $24 \mathrm{~h}$ with IL-1 $\beta$ or IL-6 at various concentrations. The rate of immunoreactive PTH-rP formation increased in a dose dependent manner with these agents. The addition of IL-1 $\beta$ $(10 \mathrm{ng} / \mathrm{ml})$ and IL-6 $(10 \mathrm{ng} / \mathrm{ml})$ resulted in a significant increase in PTH-rP. The results were analyzed by one-way ANOVA with repeated measures. ${ }^{*} \mathrm{p}<0.01$, compared with nonstimulated control.

$\mathrm{ng} / \mathrm{ml}$ ) (Fig. 3). TPA and forskolin resulted in a significant increase in ir-PTH-rP levels $3.7(p<0.005)$ and 1.7 fold higher than the control $(\mathrm{p}<0.05)$, respectively (Fig. 4).

\section{Effect of cytokines, TPA and forskolin on PTH-rP mRNA in human amnion cells}

IL-1 $\beta(10 \mathrm{ng} / \mathrm{ml})$, IL-6 $(10 \mathrm{ng} / \mathrm{ml})$, TPA $(100 \mathrm{nM})$ and forskolin $(1 \mathrm{mM})$ increased the expression of PTH-rP mRNA $(\sim 1.6 \mathrm{~kb})$. The ratio of PTH-rP to $\beta$-actin mRNA increased to $6.6,30,26$, and 19 fold higher than the control, respectively (Fig. 5). The procedure was repeated and similar results were obtained in amnion cells from other pregnant woman.

\section{Discussion}

Several investigators reported that concentrations of PTH-rP in amniotic fluid were approximately 15 fold higher than those of PTH-rP in maternal and umbilical venous and arterial plasma [11, 12]. The level of PTH-rP mRNA in amnion was much higher than that in chorion laeve, decidua and placenta $[6$, 20]. This suggested an important role of the am- 


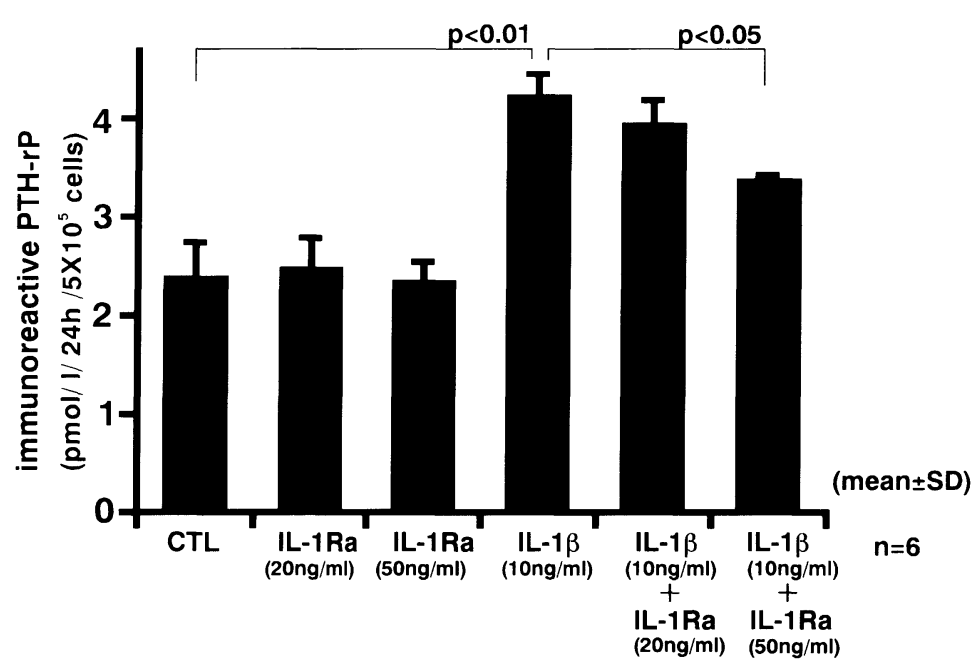

Fig. 3. Human amnion cells were isolated and maintained in monolayer culture. $80 \%$ confluent amnion cells [preincubated for $24 \mathrm{~h}$ in serum free medium] were treated with IL-1 Ra $(20 \mathrm{ng} / \mathrm{ml}, 50 \mathrm{ng} / \mathrm{ml}), \mathrm{IL}-1 \beta(10 \mathrm{ng} / \mathrm{ml})+\mathrm{IL}-1 \mathrm{Ra}(20 \mathrm{ng} / \mathrm{ml}) \mathrm{and}$ IL-1 $\beta(10 \mathrm{ng} / \mathrm{ml})+\mathrm{IL}-1 \mathrm{Ra}(50 \mathrm{ng} / \mathrm{ml})$ for $24 \mathrm{~h}$. Treatment with IL-1Ra $(20 \mathrm{ng} / \mathrm{ml}, 50 \mathrm{ng} / \mathrm{ml})$ did not have any affect on PTH-rP production. The rate of ir-PTH-rP formation (accumulation) decreased significantly with IL-1 $\beta$ (10 $\mathrm{ng} / \mathrm{ml})+\mathrm{IL}-1 \mathrm{Ra}(50 \mathrm{ng} / \mathrm{ml})$. The results were analyzed by one-way ANOVA with multiple comparison tests.

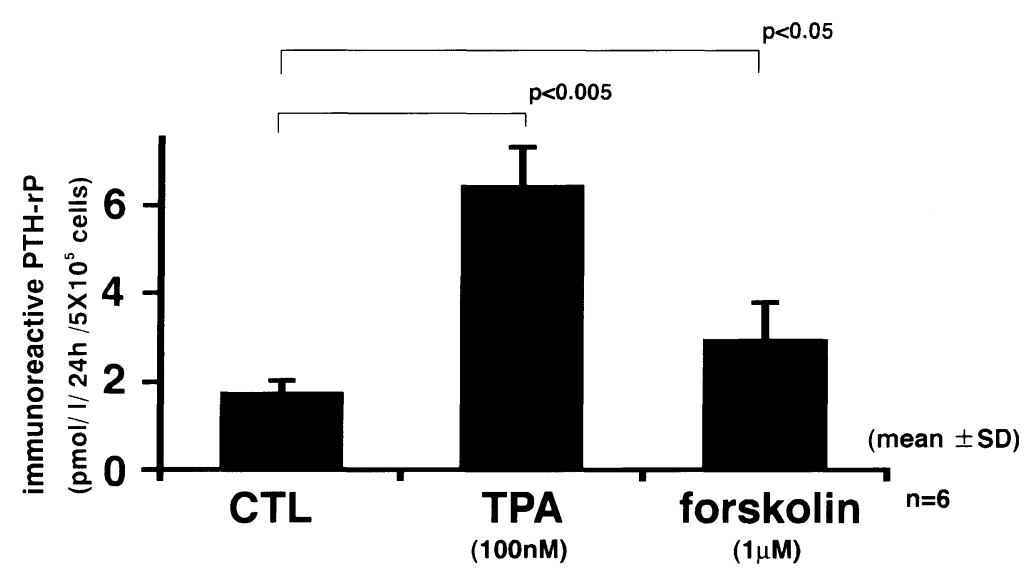

Fig. 4. To investigate the participation of protein kinase $\mathrm{A}$ or protein kinase $\mathrm{C}$ on $\mathrm{PTH}-\mathrm{PP}$ production in amnion cells, amnion cells were treated with tetradecanoyl phorbol acetate (TPA) $(100 \mathrm{mM})$ or forskolin $(1 \mathrm{mM})$ for $24 \mathrm{~h}$. Both TPA and forskolin increased PTH-rP levels by 3.7 and 1.7 fold higher than the control, but the effect of TPA was much greater than that of forskolin. The results were analyzed by one-way ANOVA with multiple comparison tests.

niotic membrane as a source of PTH-rP during pregnancy. PTH-rP stimulates by way of the PTH/PTH-rP receptor to increase adenylate cyclase activity and acts in smooth muscle cell as a relaxant in many tissues including myometrial smooth muscle [21]. Ferguson et al. found that PTH-rP mRNA abundance in amnion decreases during labor at term and mentioned that the possibility of a reduction in PTH-rP expression in amnion may play either a primary or a permissive role in the onset of labor [6].
The mechanisms of regulation of PTH-rP in amnion have not been clearly defined yet. Mitchell et al. measured ir-PTH-rP in a culture of amnion cells and found that treatment with IL- $1 \beta$ stimulates PTH-rP production by these cells [22]. In the present study we further investigated mechanisms of PTH-rP production by inflammatory cytokines in amnion cells. Production of ir-PTH-rP in human amnion cells was enhanced by IL- $1 \beta$ and IL-6 in a dose dependent manner. PTH-rP mRNA expression also 

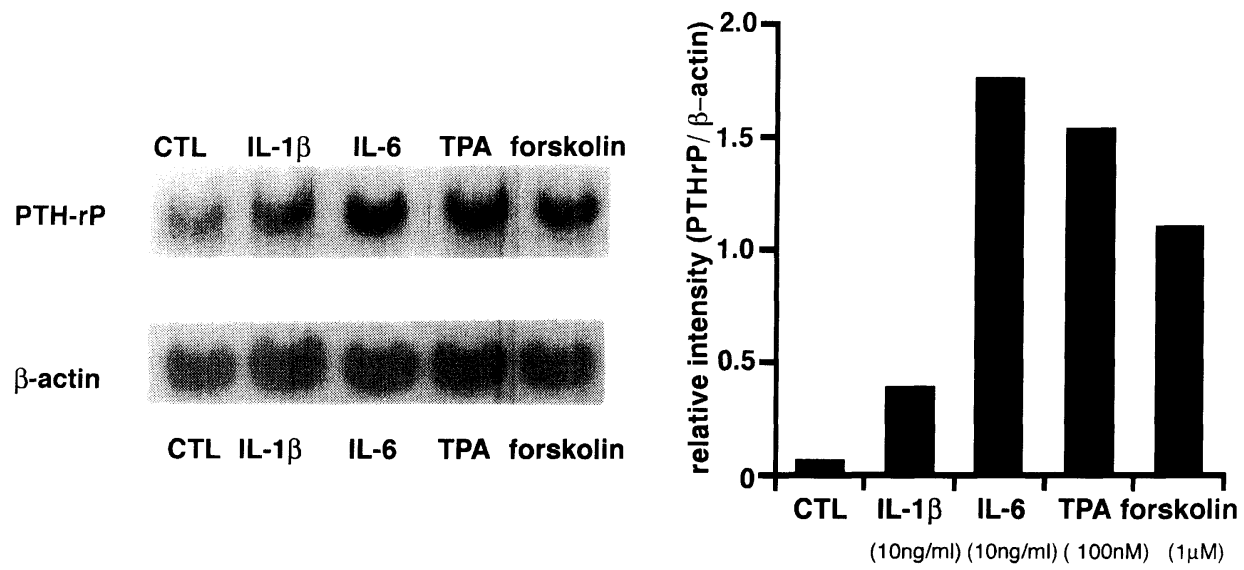

Fig. 5. Amnion cells were treated with IL- $1 \beta(10 \mathrm{ng} / \mathrm{ml})$, IL-6 $(10 \mathrm{ng} / \mathrm{ml})$, TPA $(100 \mathrm{mM})$ or forskolin $(1 \mathrm{mM})$ for $6 \mathrm{~h}$. Total RNA was isolated from the cells and the levels of PTH-rP mRNA were determined by Northern blot analysis. Membrane was hybridized with PTH-rP cDNA or b-actin cDNA (left panel). The right panel shows the ratio of PTH$\mathrm{rP} / \beta$-actin intensity which was measured with an imaging densitometer (BIO-RAD).

was increased by IL-1 $\beta$ and IL-6. Enhancement of PTH-rP in amnion cell was regulated by the translation level. In our findings, there is a discrepancy between the amount of ir-PTH-rP accumulation and expression of PTH-rP mRNA by IL-1 $\beta$ and IL-6. Since an AU rich region exists in the $3^{\prime}$ - untranslated region, PTH-rP mRNA is known to be unstable [23]. Rapid turnover of PTH-rP mRNA may be the reason for this discrepancy. When IL-1Ra was added to the medium, the increase in ir-PTH-rP production was diminished. This suggested that IL- $1 \beta$ might act on amnion cells to stimulate $\mathrm{PTH}-\mathrm{rP}$ production via IL-1 receptor. To evaluate the role of proteinkinase- $\mathrm{A}$ and $\mathrm{C}$ in the regulation of PTH-rP production, we used TPA and forskolin. TPA and forskolin enhanced the production of ir-PTH-rP and PTH-rP mRNA, but the effect of TPA was much greater than that of forskolin. Other investigators also have demonstrated that PTH-rP gene expression is altered by mechanisms that involve activation of protein-kinase-A and $C$ [24-27]. In a previous report, we demonstrated that IL- $1 \alpha / \beta$, epidermal growth factor (EGF), transforming growth factor- $\beta$ (TGF- $\beta$ ), platelet derived growth factor (PDGF), TPA and forskolin increased PTH-rP mRNA in human myometrium cells [21].

It is known that PTH-rP might modify myometrial contractility during pregnancy by way of PTH/ PTH-rP receptor, which is linked to G-proteins.
Prostaglandins produced by decidua in response to the increase in inflammatory cytokines increased the uterine contraction, but the possibility that PTH-rP produced in amnion cells affects uterine quiescence is still questionable, because it is unclear yet whether PTH-rP from amnion cells is able to reach to myometrium directly or not. The physiological roles of PTH-rP in amniotic fluid have yet to be clearly defined but several possibilities exist. Evidence suggests that PTH-rP may influence growth and/or differentiation of skin cells and bone $[28,29]$ and stimulate surfactant synthesis in rat fetal lung [30]. Since mice homozygous for the PTH-rP null mutation died postnatally [31], PTH-rP in amniotic fluid may play an important role in fetal development.

The present study did not elucidate whether PTH$\mathrm{rP}$ produced from amnion can act on the myometrium or not. Further investigation is necessary to define the physiological role of PTH-rP produced from amnion on both uterine quiescence and fetal development.

\section{Acknowledgments}

The authors are grateful to Otsuka Pharmaceutical Co., Ltd. (Tokyo Japan) for contributing recombinant human interleukin-1 $\beta$. 


\section{References}

1. Suva LJ, Winslow GA, Wettenhall EH, Hammonds RG, Moseley JM, Diefenbach-Jagger H, Rodda CP, Kemp BE, Rodriguez H, Chen EY, Hudson PJ, Martin TJ, Wood WI (1987) A parathyroid hormone-related protein implicated in malignant hypercalcemia; cloning and expression. Science 237: 893896.

2. Rodda CP, Kubota M, Heath JA, Ebeling PR, Moseley JM, Care AD, Caple IW, Martin TJ (1988) Evidence for a novel parathyroid hormone-related protein in fetal lamb parathyroid glands and sheep placenta; comparisons with a similar protein implicated in humoral hypercalcemia of malignancy. $J$ Endocrinol 117: 261-271.

3. Abbas SK, Pickerd DW, Illingworth D, Storer J, Purkie DW, Moinz C, Dixit M, Caple IW, Ebeling PR, Rodda CP, Martin TJ, Care AD (1990) Measurement of parathyroid hormone-related protein in extracts of fetal parathyroid glands and placental membranes. J Endocrinol 124: 319-325.

4. Thiede MA, Daifotis AG, Weir EC, Brines ML, Burtis WJ, Ikeda K., Dreyer BE, Garfield RE, Broadus AE (1990) Intrauterine occupancy controls expression of the parathyroid hormone-related peptide gene in preterm rat myometrium. Proc Natl Acad Sci USA 87: 6969-6973.

5. Moseley JM, Hayman JA, Danks JA, Alcorn D, Grill V, Southby J, Horton MA (1991) Immunohistochemical detection of parathyroid hormonerelated protein in human fetal epithelia. J Clin Endocrinol Metab 73: 478-484.

6. Ferguson JEII, Gorman JV, Bruns DE, Weir EC, Burtis WJ, Martin TJ, Bruns ME (1992) Abundant expression of parathyroid hormone-related protein in human amnion and its association with labor. Proc Natl Acad Sci USA 89: 8384-8388.

7. Germain AM, Attaroglu H, MacDonald PC, Casey ML (1992) parathyroid hormone-related protein mRNA in avascular human amnion. J Clin Endocrinol Metab 75: 1173-1175.

8. Ishikawa E, Katakami $\mathrm{H}$, Hidaka $\mathrm{H}$, Ushiroda $\mathrm{Y}$, Ikeda T, Ikenoue T, Matsukura S (1992) Characterization of parathyroid hormone-related protein in human term placenta. Endocrinologia Japon 39: 555-561.

9. Shew RL, Yee JA, Kliewer DB, Keflemariam YJ, McNeill DL (1991) Parathyroid hormone-related protein inhibits stimulated uterine contraction in vitro. J Bone Miner Res 6: 955-959.

10. Pitera AE, Smith GCS, Wentworth RA, Nathanielsz PW (1998) Parathyroid hormone-related peptide (1 to
34) inhibits in vitro oxytocin-stimulated activity of pregnant baboon myometrium. Am J Obstet Gynecol 179: 492-496.

11. Hirota Y, Anai T, Miyakawa I (1997) Parathyroid hormone-related protein levels in maternal and cord blood. Am J Obstet Gynecol 177: 702-706.

12. Rina D, Avraham G, Niva J, Gideon Y, Itzhak O, Zvi S, Yosef W (1995) Amniotic fluid and plasma levels of parathyroid hormone-related protein and hormonal modulation of its secretion by amniotic fluid cells. Eur J Endcrinol 133: 277-282.

13. Wlodek ME, Ho PWM, Rice GE, Moseley JM, Martin TJ, Brennecke SP (1995) Parathyroid hormone-related protein (PTH-rP) concentrations in human amniotic fluid during gestation and at the time of labour. Reprod Fertil Dev 7: 1509-1513.

14. Curtis NE, Ho PWM, King RG, Farrugia W, Moses EK, Gillespie MT, Moseley JM, Rice GE, Wlodek ME (1997) The expression of parathyroid hormonerelated protein mRNA and immunoreactive protein in human amnion and choriodecidua is increased at term compared with preterm gestation. J Endcrinol 154: 103-112.

15. MacDonald PC (1997) Parturition. In: Cunningham FG, MacDonald PC, Gant NF, Leveno KJ, Gilstrap III LC, Hankins GDV, Clark SL (eds) Williams obstetrics 20th edition. Appleton \& Lange, Connecticut 307-313.

16. Greig PC, Ernest JM, Teot L, Erikson M, Talley R (1993) Amniotic fluid interleukin-6 levels correlate with histologic chorioamnionitis and amniotic fluid cultures in patients in premature labor with intact membranes. Am J Obstet Gynecol 169: 1035-1044.

17. Otsuki K, Yoda A, Saito H, Mitsuhashi Y, Toma Y, Shimizu Y, Yanaihara T (1999) Amniotic fluid lactoferrin in intrauterine infection. Placenta 20: 175179.

18. Okita JR, Sagawa N, Casey ML, Snyder JM (1983) A comparison of human amnion tissue and amnion cells in primary culture by morphological and biochemical criteria. In vitro 19: 117-126.

19. Ikeda K, Ohno H, Hane M, Yokoi H, Okada M, Honma T (1994) Development of a sensitive two-site immuno-radiometric assay for parathyroid hormonerelated peptide; evidence for elevated levels in plasma from patients with adult T-cell leukemia/lymphoma and B-cell lymphoma. J Clin Endocrinol Metab 79: 1322-1327.

20. Alfedo MG, Hankan A, MacDonald PC, Casey ML (1992) Parathyroid hormone-related protein mRNA in a vascular human amnion. J Clin Endocrinol Metab 
75: 1173-1175.

21. Morimoto T, Devora GA, Mibe M, Casey ML, MacDonald PC (1997) Parathyroid hormone-related protein and human myometrial cells; action and regulation. Mol Cell Endocrinol 129: 91-99.

22. Mitchell MD, Hunter C, Dudley DJ, Varner MW (1996) Significant decrease in parathyroid hormonerelated protein concentration in amniotic fluid with labour at term but not preterm. Reprod Fertil Dev 8: 231-234.

23. Ikeda K, Lu C, Weir EC, Mangin M, Broadus AE (1990) Regulation of parathyroid hormone-related peptide gene expression by cycloheximide. $J$ Biol Chem 265: 5398-5402.

24. Rodan SB, Wesolowski G, Ianacone J, Thiede MA, Rodan GA (1989) Production of parathyroid hormone-like peptide in human osteosarcoma cell line: stimulation by phorbol esters and epidermal growth factor. J Endocrinol 122: 219-227.

25. Rene R, Michel LA, Andre PS, Jean-Philippe B (1994) Cyclic AMP increases the release of parathyroid hormone-related protein from a lung cell line. Int J Cancer 56: 422-426.

26. Ikeda K, Okazaki R, Inoue D, Ogata E, Matsumoto T (1993) Transcription of the gene for parathyroid hormone-related peptide from the human is activated through a cAMP-dependent pathway by prostaglan- din E1 in HTLV-I-infected T cells. J Biologic Chemist 268: 1174-1179.

27. Deftos LJ, Gazdar AF, Ikeda K, Broadus AE (1989) The parathyroid hormone-related protein associated with malignancy is secreted by neuroendocrine. $\mathrm{Mol}$ Endocrinol 3: 503-508.

28. Kaiser SM, Sebag M, Rhim JS, Kremer R,Goltzman D (1994) Antisense-method inhibition of parathyroid hormone-related peptide production in keratinocyte cell line impedes differentiation. Mol Endocrinol 8: 139-147.

29. Karaplis AC, Luz A, Glowacki J, Bronson RT, Tybulewicz LJ, Kronenberg HM, Mulligan RC (1994) Lethal skeletal dysplasia from target disruption of the parathyroid hormone-related peptide gene. Genes \& Dev 8: 277-289.

30. Rubin LP, Kifor O, Hua J, Brown EM, Torday JS (1994) Parathyroid hormone (PTH) and PTH-related protein stimulate surfactant phospholipid synthesis in rat fetal lung, apparently by a mesenchymal-epithelial mechanism. Biochemica et Biophysica Acta 1223: 91100.

31. Karaplis AC, Kronenberg HM (1996) Physiological roles for parathyroid hormone-related protein; Lessons from gene knockout mice. Vitamin and Hormones 52: 177-193. 